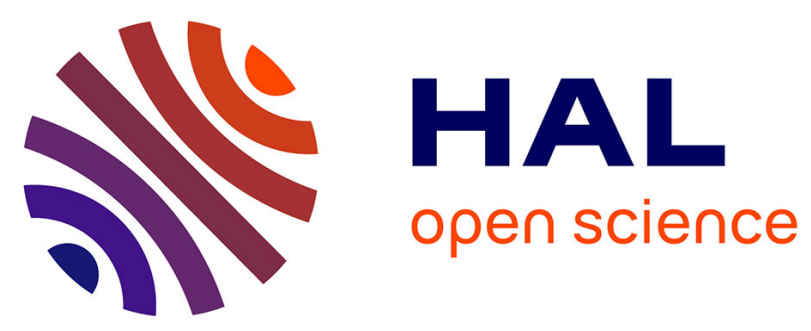

\title{
Research in Africa for Africa? Probing the Effect and Credibility of Research Done by Foreigners for Africa
}

\author{
Munyaradzi Mawere, Gertjan van Stam
}

\section{To cite this version:}

Munyaradzi Mawere, Gertjan van Stam. Research in Africa for Africa? Probing the Effect and Credibility of Research Done by Foreigners for Africa. 15th International Conference on Social Implications of Computers in Developing Countries (ICT4D), May 2019, Dar es Salaam, Tanzania. pp.168-179, 10.1007/978-3-030-19115-3_14. hal-02281299

\section{HAL Id: hal-02281299 \\ https://hal.inria.fr/hal-02281299}

Submitted on 9 Sep 2019

HAL is a multi-disciplinary open access archive for the deposit and dissemination of scientific research documents, whether they are published or not. The documents may come from teaching and research institutions in France or abroad, or from public or private research centers.
L'archive ouverte pluridisciplinaire HAL, est destinée au dépôt et à la diffusion de documents scientifiques de niveau recherche, publiés ou non, émanant des établissements d'enseignement et de recherche français ou étrangers, des laboratoires publics ou privés. 


\title{
Research in Africa for Africa? Probing the Effect and Credibility of Research Done by Foreigners for Africa
}

\author{
Munyaradzi Mawere ${ }^{1}$ and Gertjan van Stam² \\ ${ }^{1}$ Great Zimbabwe University, Masvingo, Zimbabwe \\ ${ }^{2}$ Macha Works, Zambia \\ corresponding author: gertjan@vanstam
}

\begin{abstract}
This paper probes research being carried out by researchers foreign to Africa. From an assessment of decennia of research, we address the many and varied ways in which the work of foreign researchers, often from countries with unresolved colonial baggage, cast their normalising shadows over African realities. From experiences in Mozambique, Zambia and Zimbabwe, among others, through the exposit of the complex and expansive array of influences and coloniality, we paint a picture how foreign researchers benefit from enshrined and ongoing practices that dominate research scenes. These practices depreciate African research and development done by Africans, in Africa for utilisation in Africa. We propose the need to mainstream decoloniality and communiversity as to affect the primacy of African researchers researching in, on and for Africa.
\end{abstract}

Keywords: Foreign researchers, Africa, coloniality

\section{Introduction}

Research in Africa, as the production of knowledge itself, is political. It is political because more often than not, research in Africa is carried out by foreign researchers whose objectives are sometimes not only biased but nefarious. This situation renders research in, on, and for Africa by foreign researchers suspicious and problematic.

In this paper, we probe research for Africa by researchers flying in from outside Africa by reframing such research within understandings of stigmatisation and discrimination. These vices follow each other in social processes that can only be understood in relation to broader notions of power and domination. In this probing, we move beyond narratives of research collaborations being portrayed as mostly ahistorical, apolitical, and non-racial. Negating histories, power distances, and diverse epistemologies are part of a panoptical and normalising situation that Bert Olivier [1] shows to be part of an ongoing colonisation of universities by neo-liberal or capitalistic approaches.

The authors are members of communities in rural and urban areas of Southern Africa, involved in various research works in natural sciences and the humanities. The research incorporates the implementation and effects of Information and Communication Technologies in Mozambique, Zambia, and Zimbabwe, on a daily basis. In this work, we engage with local, national and international communities and 
researchers (in that order). In this paper, we reflect on our experiences in operational research collaborations, conference visits, and academic-administrative communications encountered in over ten consecutive years of research practice in Africa.

We note that foreign researchers in Africa are often closely related to:

- countries or institutes that were benefitting from colonial power meddling

- countries that are still connected to colonialism, in fact, bolster neo-colonialism

- countries or institutes that never have said sorry for colonialism they initiated and perpetuated on Africa

- institutes and corporate businesses that, in fact, perpetuate super-colonialism, being the scaled-up colonial practice of subjugation of other people and groups for the gain of colonial agents [2]

- dominant normative epistemologies that do not align with the dynamic and integrative epistemologies that are common in Africa.

We recognise a stigma that affects work by African researchers. Often, their work is subalternised in processes where foreign researchers waltz in and impose what they want Africans to do. Tyler and Slater [3] call for the unearthing of the underlying conditions that create stigma - the 'why' and 'for whose benefit'. There are (perceived) power distances, asymmetries and powerful framings that subjugate and label African researchers and their work [4]. Further, researchers from foreign realms have direct access to, and use, industries that are local to their environment. However, those non-African industries are practically unapproachable for African researchers. Subsequently to data-collection, foreign researchers often (mostly?) appropriate the data and take it abroad. Data is not only used in objectification of the African situation. It provides advantages to foreigners to harvest information and turn data into knowledge and, subsequently, seek rent. Wa Thiongo'o [5] and Nhemachena et al. [6], among others, show how such knowledge is deployed to work against the people that have been researched. The misappropriation of data and information has compromised the quality, validity and legitimacy of research on Africa by foreign researchers, especially those linked in with Africa's former colonisers. Although the local decisions on research ethics must supersede any foreign body, in practice, local ethics may be omitted, ignored or overridden by ethics review meetings outside of Africa.

A persistent stream of research outputs presented by foreign researchers about Africa for Africa subalternates local, African researchers. This supports an epistemicide of African meaning-makings. Owusu [7] argues, "the validity of African ethnographies and researches by foreigners, have often been compromised due to an over-reliance on theoretical work from elsewhere. Actual evidence available in the field has frequently been disregarded, while the writing flair of the ethnographer has often been valued more than ethnographic evidence.” Similarly, Mamdani [8] laments that Africans are seen as harvesters of information only. He "urge[s] to examine the processes of power and profit”. We add here that these processes are complex and require intellectual rigour.

This paper critically interrogates the effect and credibility of research in, on, and for Africa by foreign researchers. We focus on communiversity counter to the 
dominance of university to destabilise a normative epistemology that bifurcates between subject-object and the researcher-researched narratives, paradigms dominant in academia.

\section{The coloniality of research in Africa}

Gonzales et al. [9] show that in HIV health research in Africa, foreign research institutions and international NGOs are responsible for almost $60 \%$ of the research. Being sensitised by their observation, we critically analysed the evidence presented at the prestigious International Aids Society meeting (IAS) in 2017 to quantify the African contributions. South Africa was responsible for $15 \%$ of the research while the input from African researchers outside of South Africa was a paltry $19 \%$. These numbers show a clear dominance of foreign researchers presenting views, and normalising, a disease that disproportionally hits the African continent, affecting millions of people.

The unavailability of research outputs from Africa resonates with Geldof's (2010) observation on the dearth of literature on ICT in Africa by Africans on the continent. In her study on literacy and ICT in Ethiopia and Malawi, Geldof [10] noted how she found little literature that pays explicit attention to the positionality of foreign researchers compared to local researchers or how this impacts the research process as a whole. Her writings and similar research papers, however, seem to narrow down issues to language barriers and cultural misunderstandings only. For instance, in their review of 'non-technical aspects' of information and communication technology (ICT) in international development, Kemppainen et al. [11] did not show any sensitivity towards 'who researches' what and where. Not surprisingly, they deduced that 'the alignment with international political and development agenda' is crucial for 'improving ICT oriented development projects', something we contest in this paper. Of course, there could be reports addressing issues we mention in this paper. However, when paywalls guard such documents, they are rendered inaccessible and void to African researchers like us.

ICT research in Africa appears to be Eurocentric, colonial and hegemonic. It remains undergirded and trapped in what Ndlovu-Gatsheni [12] and others regard as the snares of a colonial matrix of power and dominance. In this matrix, foreign researchers dominate the terrain of research even where research is on Africa, carried out in Africa, and framed to be for Africa. This domination of foreign researchers is coloniality at its best as it implies an illusion of freedom and perpetuation of colonial gestures.

We experienced that foreign researchers position themselves as the main actors and gatekeepers in connections with funding partners. Such partners often demand 'leadership from a Western partner' or 'technical assistance' with a push to involve Westerners for a benefit for their (non-African) industries. This appetite for foreign control is part of concepts like Public Private Partnerships (PPP), and a 'new normal' culture of universities forced to follow neoliberal schemes that demand marketisation. This marketisation relies on ideologies heralding the benefits of corporatisation, 
commercialisation, and privatisation of education and research [13]. In PPPs, Western-based corporate partners often look over the shoulders of researchers, seeking rent by levering market powers and first entry advantages. In this scramble, humanitarian aid or corporate responsibility programs are being used to facilitate market entry for companies [14]. These capitalistic processes result in weaponised research endeavours that fuel the apparent insensitivity and power-laden manners in which foreign researchers interact in Africa. As a result, the outcomes, or research collaborations, mostly negate and defy the loud voices demanding epistemic liberation and research independence which have become recurrent in Africa and elsewhere since the beginning of decolonisation project in the late 1950s and early 1960s. Such observations warrant serious rethinking and reconsideration if research in and on Africa by foreign researchers is to pass the rigour and logic of social and epistemic justice in objective research. Therefore, we argue for a communiversity instead of the dominant university narrative where those at the latter are purported to be sole knowers, knowledge producers and custodians of knowledge.

\section{The powerhouse of coloniality in research work for Africa}

Quijano [15] presents coloniality as a system that defines the organisation and dissemination of epistemic, material and social resources in ways that reproduce modernity's imperial projects. To this understanding, Maldonado-Torres [16] adds that "coloniality refers to long-standing patterns of power that emerged as a result of colonialism, but that define culture, labour, intersubjective relations, and knowledge production well beyond the strict limits of colonial administrations.” These patterns of power remain standing in contemporary African states in the name of the so-called modernity, which for many critical scholars is an extension of colonialism and a manifestation of coloniality. Grosfoguel [17], for instance, argues that "coloniality and modernity constitute two sides of a single coin. The same way as the European industrial revolution was achieved on the shoulders of the coerced forms of labour in the periphery, the new identities, rights, laws, and institutions of modernity such as nation-states, citizenship and democracy were formed in the process of colonial interaction with, and domination/exploitation of, non-Western people." Similarly, Zembylas [15] brings coloniality and modernity together. He regards coloniality as the underlying logic that places peoples and knowledge into a classification system such that all that is European is valorised while all that is non-Western is despised or condemned. The colonial matrix of power and knowledge, therefore, serves only a small portion of the global society - the elite - that benefits from the dominant and hegemonic Eurocentric belief systems that regarding epistemology implies a 'one size that fits all'. Coloniality, modernity, and capitalism thus go hand-in-hand - they have the same underlying philosophy.

The \#Rhodesmustfall movement sparked a renewed interest in decolonising higher education (and thus research) in South Africa [18] and in Africa in general. In contemporary times, in line with political realities of interest in the continuing colonial meddling and the narrative of an African renaissance, a growing realm of 
African presidents are highlighting local agency. They advocate wholesomely rejection of foreign aid as an agent of geopolitical meddling. Former African statesmen like Mbeki (of South Africa) and Mugabe (of Zimbabwe) have, throughout their history as presidents, been critical of foreign aid which they consistently criticised as agents of imperial powers.

Nyamnjoh [19] links an ideology of modernism to research. He describes how the demand for modernism and its promises have been the main engine for methodological import from outside of Africa. He questions how, given its apparent result in decennia of underdevelopment, related research practices have continued in Africa. He states "modernisation has survived more because it suits the purposes of its agents than because of its relevance to understanding the African situation. Those who run international development programmes along the Western model inspired by Modernisation Theory, "are not interested in challenge, stimulation and provocation at any level". They want their programmes to go on without disturbance and would only select as researchers or accept only those research questions and findings that confirm their basic assumptions on development in Africa." [19].

The Africa failing narrative which appears persistent in literature has resulted in a discourse of deficiency and incompetence, framing African research and researchers as lacking academic and professional resource. Regarding research, it is a discourse that partly explains the situation in which Africa finds itself today.

Burawoy [20] shows how positive science tries to negate power influence, an effort that, in environments outside of the dominant power-that-be (and, most probably also within) can be considered futile. It was Fanon [21] who revealed the effects of colonial subjectivation. He describes psychological trauma being caused by the instilling of negative pictures. Such injury is caused early in a learning environment saturated by 'white' supremacy that does not value (and actively devalues) persons of colour. The result is psychological colonisation through an imposed racist phenomenology that seeks to imprint a sense of inferiority in the minds of people of colour. Further, Fanon shows how, through those interactions - with histories and within the material world as well as ideas - the source of the matter becomes acutely exposed. Fanon actively rejects the idea that amendments to the local realities should come from input from the outside. Such input, he argues, should be rejected.

\section{The decolonisation of relationships and common sense}

The African realities and their negotiations with non-African realities are set in structural narratives and structuring discourse and make their appearances through paradigms and epistemologies. They have been influenced, and are shaped, through perceptions of time, view on histories, geographies, religious, political and economic relationships. These are all social processes. Foreign research in Africa, with dominance and imperial gestures therein, has a long and questionable history. For example, African anthropologists discovered some gross mistranslations and misinterpretations of oral traditions in texts from accounts about African culture by 
Western anthropologists [22]. Others have pointed to the existence of a 'white saviour' syndrome.

African study centres in Europe started as research institutes to support colonial conquest in Africa and elsewhere [23]. However, it is not necessarily the social cognitive understanding that informs us why the contemporary situation is the way it is. The questioning of foreign researchers performing research in, on and for Africa is not a problem of a sub-set in ICT4D, nor limited to any field of study. Although the contemporary situation makes collaboration and cooperation difficult and lopsided, these are not contentions between individuals. They are the result of structures in society that have grown to be super-colonial. They are the continuation of an orientalistic, imperial academy that continues to benefit from the ongoing situation as the recipient of data, information, existing powers to create knowledge and to make a living out of it for its (Western) workforce. No wonder, that esteemed Ugandan researcher Mahmood Mamdani [8] cynically noted that in research collaborations Africa could only solicit for the crumbs as hunters and gatherers of raw data, as native informants who collect and provide empirical data for processing in West, and the empowerment of the elite.

The Burundian scientist, Bigirimana [24, 25] describes how a normative epistemology introduced from an externalised knowledge is presented as authoritative because it is positioned as indubitable, infallible and incorrigible. This positioning aligns with Burawoy's [20] assessment of a positive science that relies on the '4R's', being representative, reactive, reliable and replicable. Both authors problemise these approaches as harbouring dichotomies and removed from the complexity of power. The use of the amended methods as in post-positivism and constructivisticinterpretivistic and critical-ideological methods seem not to deal with the outset of regarding knowledge as existing separate of the knower, and thus as being available 'to be harvested'. The results of any of such method are further problematised by their dominant use, being focused on the individual, in line with a long history of objectifying Africa, Africans and African realities. A consistent framing of 'individuals' and reflecting on his effectiveness or self-actualisation have set how measures of success are being defined. Subsequently, in line with the Adagio of 'what gets measured gets done', conceptualisation of technologies and reports on their implementation are set to echo such a discourse of 'success'.

Indirectly, the Ghanaian Annan stood against such individualism. Preceding his passionate arguments for democracy, he commented on the politic of human beings stating that "Man is born, lives and dies as a member of a community and the affairs of that community are therefore his and vice-versa." [26] However, dominant neoliberal anthropocentric approaches continue to put 'the individual' at the centre of attention. Such centrality supports divisions, as it pitches 'one-against-the-other' in a competitive world, allowing foreign researchers to research in and on Africa without being an integral part and member of the community in which the research takes place. Individualism, also, strives in dichotomies, where opposing and mutually exclusive positions are assigned to thinking and doing. Bifurcations undergird the dungeons of scientism or culturism. The resulting fights over boundaries have taken away the academic attention to the value of altogether different and integrated ways 
of knowing, although there are clear signals of their existence in non-Western literature or counter-narratives.

Is it, therefore, that the research cooperations in ICT4D have little to show as for societal impact? Do we apply the right lenses [27]? We highlight here that the sociopolitical context puts up severe challenges to accost inherited and super-colonial practices and structures that have been purposely planted to dominate. To make matters worse, the (mostly western-based) collectors of data get more and more powerful. Their platforms are regarded to have accumulated much value, their foreign based and led research networks continue to measure and control. The relatively limited impact of ICT4D might well be related to these inherent flaws and the limitations because of theoretical and methodological scarcity leading to an echochamber of lopsided attention to foreign, Western epistemology. The subalternising of African researchers and their agency to study their environment (like Western researchers do in their Western environments), is part of what Bourdieu [28] called 'symbolic violence'. Therefore, the effect of foreign researchers must be placed in meso and macro socio-cultural structure and power, especially as in the capitalistic scheming of 'the market'. Western researchers are often well embedded in the rhetoric of (the Western rendering of) modernity as a means to salvation for development or poverty alleviation. This hegemony limits the potential of epistemic disobedience [29] that can shed light on African life, the varied ways of knowing and how to institutionalise them.

For fruitful research for Africa in Africa, there is a need to thoroughly understand the local epistemologies by living-the-life and gleaning inputs from local, African philosophies. Although put outside of the limelight, often tough to access, and relatively under-researched, among others, the studying of African cultural heritages provides narratives on how meaning-making is lived in a community. The vocabularies of knowing in African environments present a gateway to understanding how many Africans sustain their cultural identities against the (often technology enabled) onslaught of orientalism, imperialism, and colonialism that fuelled Africa's disenfranchisements for over 500 years. There is little evidence of foreign researchers in ICT4D showing sensitivity to incorporate these perspectives. African epistemologies are dynamic and integrative, understanding knowing as an act of the knower and knowledge being a quadrichotomy of emotional, intellectual, evaluating and pragmatic forms [24]. Method, of course, is subject to the epistemic base and philosophy of knowing, and, in the case of the dynamic and integrative epistemology of the local community, methodological approaches must be aligned with the level of consciousness one is focussing on.

There appears a consistent undervaluing of local methods of research to unearth a dynamic and integrative (and thus evolving) local knowing in a community of inquiry [30] involving human and non-human inputs. In the meantime, researchers in African universities are between a rock and a hard place [31], as they are both stigmatised, or feel inferior. This situation disempowers the enactment of alternative views enlightened by African value systems as they are not (yet) accepted in the Westernoriented universities. Further, in international cooperations, often African researchers are supposed to align with neo-liberal motives of institutes and states that are, 
inherently, colonial from the African perspective: they shame, brainwash and meter out resources via them [2]. Those that wish to include methods set in African philosophies are mostly rejected because of such methods being typified 'idiosyncratic' [32]. Mainstream sciences generally marginalise the output of African research set in African philosophies. For instance, the African research work in TV White Spaces is overshadowed by the onslaught of information from Western institutes. Actually, in publications, reference of western authors or activities is seen as 'compulsory, while Western publications do not necessarily cite the groundbreaking research taking place in Africa by Africans [e.g. in 33].

ICT4D cooperations and ICT technologies are relatively new. However, Dourish and Mainwaring [34] showed how the ubiquitousness of the information and communication technologies is inherently colonial. Therefore, the negation of local researchers, or keeping them as 'suppliers of raw data', remains a productive situation for foreigners in the African environment. It is a force that enables the structures, mechanisms, and justifications of power to function in the current, super-colonial fashion.

We have observed that research by Africans on the continent is stigmatised and often despised. This stigmatisation is devastating in its effects, as it isolates researchers in African universities, especially when they are not listed in (western) standardised and homogenised 'quality' criteria in global and national institutional rankings. Goffman [35] showed this attack on identity leads to passing and concealment. It acts as a means of formal social control. This social control is clear in work by Holm and Malete [36] exposing the asymmetries of research partnerships from their experience in Botswana. When we regard the African researcher as stigmatised, the work of Graham Scambler [37] becomes productive. Scrambler argues that 'stigma' is particularly weaponised in the neoliberal era. He observes (a) the distinctions between enacted and felt stigma (involving norms of shame) and enacted and felt deviance (involving norms of blame), and (b) the novel neoliberal dialectic between these two sets of norms, especially because of the dynamics of financial capitalism, which is 'lord' in research. The target is gathering of financial resources, and the vehicle is research. This focus on monetisation and extracting rent has led to a plethora of 'training' - part of colonialism as it brainwashes - where 'education' and 'schooling' to alleviate that 'shortcomings' (the stigma) is pushed for. However, we contend, there are more structural issues underlying this. It is in the assigned roles of power and structure. These power issues are many.

Possibly, what the reaction of \#RHODESMUSTFALL movement might have shown is the ridiculing and encapsulation of the African territory 'being different' then what the forces of globalisation asks compliance with. Mass unemployment of graduates and non-graduates alike and the negation of African politics and needs for decolonisation are positioned as reasons of marginalisation. Through this typification and stigmatisation of the local demand for emancipation and epistemological sovereignty [38], African research is being excluded and made even less relevant by the ones 'on top'. This negation keeps the 'African failing' narrative intact and perpetuates the thought that interventions from 'the outside' are justified and worth pursuing. This setting is part of the colonial ways, with shaming being a key element 
in perpetuating the structures of self-interest that support the unequal distributions of resources in society [39]. We must address the construction of the social structures of research 'normalcy' and how come that African researchers are considered different, or what causes (hidden) attitudes of prejudice. There is a clear need for the celebration of diversity in knowing, for the differentiation of attention, resource allocation, and focus.

\section{Discussion}

Foreign researchers are often complicit with the modernist narrative, steeped in philosophies conceptualised by Westerners in Western places [40]. They seem to thrive in normative epistemologies that do not align with the dynamic and integrated epistemologies prevalent in African settings. African epistemologies like, for instance, Ubuntu are widespread and well enshrined [41]. They are part of a long history, being present well before the advent of colonial control [42-44]. African means of knowing have led to embodied knowledge, often in response to various forms of oppression [45, 46]. The undeserved privileges of non-African researchers indirectly serve to delegitimise African ways of knowing. Thus, to question the primacy of foreign researchers to perform research in Africa for Africa (as shown in the example in HIV/AIDS research) is a question on cognitive justice that is inseparable from the struggle for social justice [45].

Examples of issues that are seemly overlooked in ICT4D research are, for instance, understanding indigenous social structures, their relation to land, the meaning of technological artefacts, and the use of taboos. These aspects of life in Africa constitute a consciousness that opposes colonial systems and, subsequently, interventions that result out of foreign research. The overshadowing of the local ways of knowing is an existential struggle. The coloniality that influences the choices in research in and on Africa denies African researchers their voice, most especially their ability to use African and local epistemic frames, with severe consequences.

A transformation of research practices in Africa would involve the disrupting of institutional cultures that guide research, publications, and funding. An example is the resource contained in the papers presented at this conference. The texts are claimed exclusively, solely, and permanently by an organisation (IFIP) and a publisher (Springer) for the financial benefit of people outside of Africa. Neither of these organisations has a workforce in Africa. Nevertheless, they gatekeep the texts and their dissemination by demanding compliance of all authors while harvesting its value by the selling of the knowledge emerging from a vital gathering of researchers and specialists. This situation represents a poignant example as to how current research and dissemination structures are set in neoliberal structures that benefit a Eurocentric elite.

When we question the effect and credibility of research done by foreigners for Africa, we examine the systems of access and management to research projects. We pose that decolonisation means reversing the systems of Eurocentric research control. Such would address and attenuate the hegemony of Eurocentric normative 
epistemologies and processes of research management, the use of individualistic anthropocentric methodologies, the authority of Eurocentric classifications, reviewing means of command and control and dissemination, the dominant system of capitalistic accountancy and research assessment systems. Decolonisation implies breaking the barriers between the researchers and the researched, in the strengthening of knowing in community [23, 30]. Reform would involve assuring pluriversalism, reorienting ways of knowing and research transcending disciplinary divisions and orientalistic, imperialistic and colonial segregations. The master narrative that research is ahistorical and apolitical, and research practices and the dissemination of its outcomes are without racism or stereotyping acts as a muffler on discussions on these issues. Being neutral means that dominant practices will continue, as the status quo of mostly foreign researchers researching for Africa is well enshrined. The continued dismantling of African agency, for instance by the established practice of inviting foreigners to research in African on Africa demands needs an academic push back. However, insisting on the primacy of African researchers for research in Africa will not go well with established partners but requires authoritative advocacy and well thought through policies.

\section{Conclusions}

Questioning the agency and effects of foreign researchers in Africa, in this paper is positioned as a profound shift of discourse towards decoloniality. The reality at hand is that the primacy of non-African researchers researching in, on and for Africa denies serious attention on the African experience and theories. They mask the complex entanglements between knowledge formations and ways of knowing. Although there is a clear need for transformation of research practices in, on and for Africa. Such a change cannot be seen outside the realm of decolonisation. This paper exposes of the dominance of Eurocentrism in research and its underlying philosophies, epistemologies and practices. Lifting the subalternising of African researchers will unearth unique ways of knowing that have been denied relevance due to a hegemonic and epistemic arrogance of long-established parties.

\section{References}

1. Olivier, B.: Truth, Power, Intellectuals and Universities. In: African Philosophy and the Future of Africa, ed. Gerard Walmsley, pp. 23-46. The Council for Research in Values and Philosophy, Washington DC (2011).

2. van Stam, G.: The Coming-of-Age of Super-Colonialism. In: Mawere, M., Mubaya, T. (eds.) African Studies in the Academy. The Cornucopia of Theory, Praxis and Transformation in Africa?, pp.13-40. Langaa RPCIG, Bamenda (2017).

3. Tyler, I., Slater, T.: Introduction: Rethinking the sociology of stigma. The Sociological Review Monographs 66, 721-743 (2018).

4. van Greunen, D., van Stam, G.: Review of an African Rural Internet Network and related Academic Interventions. The Journal of Community Informatics 10 
(2014).

5. Wa Thiong'o, N.: Decolonising the Mind: The Politics of Language in African Literature. Heinemann, Portsmouth (1986).

6. Nhemachena, A., Mlambo, N., Kaundjua, M.: The Notion of the "Field" and the Practices of Researching and Writing Africa: Towards Decolonial Praxis. Africology: The Journal of Pan African Studies 9 (2016).

7. Owusu, M.: Ethnography of Africa: the usefulness of the useless. American Anthropologist 80, 310-334 (1978).

8. Mamdani, M.: The importance of research in a university. Pambazuka News (2011).

9. Gonzalez Perez, J., Zakowicz, A., Ssamula, K., Buzaalirwa, L., Kayongo, A.: All for the Africans but nothing by the Africans? Analysis of the contribution of African HIV research institutions in the IAS 2017 conference. In: AIDS 2018, 2327 Jul 2018, Amsterdam, the Netherlands (2018).

10. Geldof, M.: Literacy and ICT: Social Constructions in the lives of Low-literate Youth in Ethiopia \& Malawi. University of London, London (2010).

11. Kemppainen, J., Tedre, M., Sutinen, E.: Development Projects and ICT: A Review of Non-Technical Aspects. EJISDC 63, 1-20 (2014).

12. Ndlovu-Gatsheni, S.: The Entrapment of Africa within the Global Colonial Matrices of Power. Journal of Developing Societies 29, 331-353 (2013).

13. Czerniewicz, L., Mogliacci, R., Walji, S., Swartz, R., Ivancheva, M., Swinnerton, B., Morris, N.: Negotiating the 'new normal': How decision makers in higher education perceive marketisation in the sector. In: HERDSA Annual Conference, 25 Jul 2018, Adelaide, Australia (2018).

14. Masaka, D.: Why Enforcing Corporate Social Responsibility (CSR) is Morally Questionable. Electronic Journal of Business Ethics and Organization Studies 13, 13-21 (2008).

15. Zembylas, M.: Decolonizing Higher Education Pedagogies: Good Intentions Are Not Enough. In UWC Decolonisation Seminar Series, 1 Dec 2017, Bellville, South Africa (2018).

16. Maldonado-Torres, N.: On the Coloniality of Being. Contributions to the development of a concept. Cultural Studies 21, 240-270 (2007).

17. Grosfoguel, R.: Decolonizing Post-Colonial Studies and Paradigms of Political Economy: Transmodernity, Decolonial Thinking, and Global Coloniality. Journal of Peripheral Cultural Production of the Luso-Hispanic World 1 (2011).

18. Nyamnjoh, F.: \#RHODESMUSTFALL. Nibbling at Resilient Colonialism in South Africa. Langaa RPCIG, Bamenda (2016).

19. Nyamnjoh, F.: Communication Research and Sustainable Development in Africa: The Need for a Domesticated Perspective. In: Gumucio-Dagron, A., Tufte, T. (eds.) Anthology: Historical and Contemporary Readings, pp. 597-609. Communication for Social Change Consortium, South Orange (2006).

20. Burawoy, M.: The Extended Case Method. University of California Press, Berkeley and Los Angeles (2009).

21. Fanon, F.: The Wretched of the Earth. Grove Press, New York (1963).

22. Appiah-Thompson, C.: The Politics of Researching Africa: The Quality of Anthropo-Historical and Linguistic Data in African Studies. Journal of Black Studies 7, 1-11 (2017). 
23. van Stam, G.: Decolonising Science: Switching the Paradigm to 'Community.' Invited Address, University of the Western Cape, Bellville, Cape Town, South Africa, 6 November 2017 (2017).

24. Bigirimana, S.: Beyond the thinking and doing dichotomy: integrating individual and institutional rationality. Kybernetes 46, 1597-1610 (2017).

25. Bigirimana, S.: Patterns of Human Knowing in the Information Society. A Philosophical Study of the Epistemological Implications of the Information Revolution. Ruprecht-Karls-University, Heidelberg (2011).

26. Annan, K.: The Crisis of Democracy. In 2017 Athens Democracy Forum, 13 Sep 2017, Athens, Greece (2017).

27. Gomez, R., Pather, S.: ICT Evaluation: Are We Asking The Right Questions? EJISDC 50 (2012).

28. Bourdieu, P.: Acts of Resistance: Against the Tyranny of the Market. The New Press, New York (1998).

29. Mignolo, W.: Introduction: The Global South and World Dis/Order. The Global South 5, 1-11 (2011).

30. van Stam, G.: Method of Research in a We-Paradigm, lessons on Living Research in Africa. In: IFIP WG 9.4 Conference, 1-3 May 2019, Dar es Salaam, Tanzania (2019).

31. Swartz, R.,Ivancheva, M., Czerniewicz, L., Morris, N.: Between a rock and a hard place: Dilemmas regarding the purpose of public universities in South Africa. Higher Education (2018).

32. Mawere, M., van Stam, G.: Paradigm Clash, Imperial Methodological Epistemologies and Development in Africa: Observations from rural Zimbabwe and Zambia. In: ed. Mawere, M. Mwanaka, T. (eds.) Development, Governance, and Democracy: A Search for Sustainable Democracy and Development in Africa, pp. 193-211. Langaa RPCIG, Bamenda (2015).

33. Johnson, D., Mikeka, C.: Bridging Africa’s Broadband Divide. IEEE Spectrum, 41-45 (2016).

34. Dourish, P., Mainwaring, S.: Ubicomp’s Colonial Impulse. In: UbiComp’12, 5-8 Sep 2012, Pittsburgh, USA (2012).

35. Goffman, E.: Stigma. Prentice-Hal, Englewood Cliffs (1963).

36. Holm, J., Malete, L.: The Asymmetries of University Partnerships between Africa and the Developed World: Our Experience in Botswana. In: Going Global 4 - The British Council's International Education Conference, 24-26 March 2010, London, UK (2010).

37. Scambler, G.: Heaping blame on shame: 'Weaponising stigma' for neoliberal times. The Sociological Review 66, 766-782 (2018).

38. Buskens, I., van Reisen, M.: Theorising agency in ICT4D: Epistemic sovereignty and transformation-in-Connection. In: Mawere, M. (ed.) Underdevelopment, Development and the Future of Africa, pp. 394-432. Langaa RPCIG, Bamenda (2016)

39. Walker, R.: The shame of poverty. Oxford University Press, Oxford (2015).

40. Hlabangane, N.: Can a Methodology Subvert the Logics of its Principal? Decolonial Meditations. Perspectives on Science 26, 658-693 (2018).

41. Mawere, M., van Stam, G.: Ubuntu/Unhu as Communal Love: Critical Reflections on the Sociology of Ubuntu and Communal Life in sub-Saharan Africa. 
In: , ed. Munyaradzi, M., Marongwe, N. (eds.) Violence, Politics and Conflict Management in Africa: Envisioning Transformation, Peace and Unity in the Twenty-First Century, pp. 287-304. Langaa RPCIG, Bamenda (2016).

42. Masaka, D.: The Impact of Western Colonial Education on Zimbabwe's Traditional and Postcolonial Educational System(s). University of South Africa, Pretoria (2016).

43. Mawere, M.: Possibilities for Cultivating African Indigenous Knowledge Systems (IKSs): Lessons from Selected Cases of Witchcraft in Zimbabwe. Journal of Gender, Peace and Development 1, 91-100 (2011).

44. Mawere, M.: African Indigenous Knowledge Systems' (IKSs) Potentialities for Establishing a Moral, Virtuous Society: Lessons from Selected IKSs in Mozambique and Zimbabwe. Journal of Sustainable Development in Africa 12, 209-221 (2010).

45. de Sousa Santos, B.: Epistemologies of the South. Routledge (2014).

46. Mawere, M., van Stam, G.: Oratio: A Framing of Knowledge in the Context of Technology and Academia. In: Munyaradzi M., Mubaya, T. (eds) African Studies in the Academy. The Cornucopia of Theory, Praxis and Transformation in Africa?, pp. 251-264. Langaa RPCIG, Bamenda, (2017). 